\title{
Winter Quarterly Meeting, 1989
}

The Winter Quarterly Meeting was held at The Royal Institute of British Architects, London on 24 and 25 January under the Presidency of Dr J. L. T. Birley.

\section{Business Meeting}

The business meeting was held on Wednesday, 25 January 1989, attended by 65 Members of the College.

\section{Minutes}

The minutes of the Autumn Quarterly Meeting held at Kensington Town Hall, London on 27 October 1988 and published in the Psychiatric Bulletin, January 1989 , were approved and signed.

\section{Registrar's report}

The College has been considering how to put its own recommendations on alcohol into practice. A document on the Doctor as Exemplar of Safer Drinking has been produced by the Substance Misuse Section and approved by Council. This will now be forwarded to the Conference of Royal Medical Colleges for approval. The Special Committee on Unethical Practices in Psychiatry has published a paper in the Psychiatric Bulletin on torture and psychiatry. Another document from the Child and Adolescent Section, on good practice concerning child sexual abuse, has also been published in the Psychiatric Bulletin. This document has gone for consideration with those produced by the British Paediatric Association and the British Association of Paediatric Surgeons. At this time the Liaison Group between the College and the British Paediatric Association has been reconstituted to provide a forum for discussion and effective action on matters of joint interest.

For some years, it has been known that there have been very poor services for young people with brain damage. The Public Policy Committee has now produced a paper with an accompanying appendix listing provision for such people all over the country and this will be sent to the Department of Health.

The College remains concerned about recent developments in the National Health Service and has considered the effect on the psychiatric services, and the regrading of nurses as it affects psychiatric nurses.

Council has discussed the involvement of Health Authority Officers in Advisory Appointments Committees, and a clear statement has been made which will be appearing in the February Psychiatric Bulletin .
The Government's review of the Health Service is awaited with keen interest, an ad hoc working committee has already been drawn up to prepare the College's response. This will be chaired by the President.

At the beginning of 1989 we look to the future and in particular to closer involvement with Europe in 1992. The General Medical Council's proposals for a specialists' register has been carefully considered. The College was pleased to see that the European Trainees' Committee has made suggestions for an upgrading of specialist training in psychiatry along the lines already in practice within the College. With our thoughts towards a closer union with Europe, we are particularly happy to have visitors at this meeting from the Hellenic Psychiatric Association.

DR ANn Gath Registrar

\section{Resolution}

The following resolution was proposed by Dr S. P. Sashidharan, seconded by Dr R. K. Brahma.

"It is resolved that the Royal College of Psychiatrists requests that the General Assembly of the World Psychiatric Association at its meeting in Athens in 1989 considers the following resolution:

In view of (i) well-documented and incontrovertible evidence of the continuing systematic and institutionalised racist policies and practice in psychiatry under the apartheid regime of South Africa and (ii) failure of the Society of Psychiatrists of South Africa to challenge or to oppose effectively such unethical and politically motivated policies and practices in the field of mental health care, the General Assembly resolves that the Society of Psychiatrists of South Africa be expelled from the World Psychiatric Association until such time as the Society of Psychiatrists of South Africa can show that these have ceased"

A show of hands (46 for, eight against) showed that the majority of those attending this meeting were in favour of the resolution.

The President clarified the situation with reference to the Regulations and he said that in view of the major importance of this resolution, and the relatively small number of people attending the Winter Quarterly Meeting, he had decided to refer the Resolution to Council who would then be able to decide either to allow a vote at the AGM or to put the matter to a postal ballot of the Membership. 